\title{
ANALYSIS OF FACTORS THAT AFFECT THE PRODUCTION OF RICE PADDY FARMING IN LUPIA VILLAGE OF KABANGKA SUB-DISTRICT MUNA DISTRICT
}

\author{
Wa Ode Chris Meiliawati ${ }^{\left.{ }^{*}\right)}$, Ayub Manggala Padangaran ${ }^{1)}$, Muhammad Arief Dirgantoro") \\ ${ }^{1}$ Department of Agribusiness Faculty of Agriculture Universitas Halu Oleo Kendari 93232 \\ *Corresponding author : waodechrismeilia@gmail.com
}

To cite this article:

Meiliawati, W., Pandangaran, A., \& Dirgantoro, M. (2021). Analysis of Factors that Affect the Production of Rice Paddy Farming in Lupia Village of Kabangka Sub District Muna District. International Journal of Agricultural Social Economics and Rural Development (ljaserd), 1(1), 1 - 7. doi:http://dx.doi.org/10.37149/ijaserd.v1i1.14161

Received: September 20, 2020; Accepted: October 31, 2020; Published: January 31, 2021

\begin{abstract}
This study aims to analyze the factors that influence the production obtained from rice farming in Lupia Village, Kabangka District, Muna District. This research was conducted in Lupia Village, Kabangka Sub District, Muna District. There were 42 respondents, conducted using the simple random sampling method (simple random sampling) using the Slovin formula. The data analysis used was Cobb-Douglas analysis. The results showed that the variables of land area, seeds, and pesticides had a significant effect on rice production, while labor, urea fertilizer, and NPK Phonska fertilizer did not have a significant effect on rice production in Lupia Village, Kabangka Sub District, Muna District.
\end{abstract}

Keywords: farming; kabangka sub-district; production factors; rice paddy

\section{INTRODUCTION}

Rice is a very important cultivation plant for mankind because more than half of the world's population depends on this plant as a source of food. Almost all Indonesians meet their food needs from rice plants. Thus, the rice plant is a plant that has spiritual and cultural values. , economics and politics are important for the Indonesian nation because they affect the lives of many people. In nature, there are thousands of rice plant varieties known to mankind, but not all of them have economic value (Utama 2015).

Southeast Sulawesi is one of the provinces in the Eastern Indonesia region which has quite extensive wetlands, some of its residents work in the agricultural sector to make ends meet so that agricultural development in the regions is emphasized a lot in this field. One of the commodities developed in Southeast Sulawesi is lowland rice. One of the districts in Southeast Sulawesi as a rice producer is Muna District where rice production in Muna District from 2014-2016 has decreased, then in 2017-2018, it has increased due to various factors. In 2014 the total production was 7,848 tons with a harvest area of 2,021 ha, in 2015 it was 5,316 tons with a harvest area of 1,582 ha, then in 2016 the total production was 2,300 tons with a land area of 939 ha, in 2017 the amount of production increased by 3,075.6 tons with a land area of 852 tons, and in 2018 the amount of production increased by 3,533.5 tons with a harvest area of 955 ha (BPS Kabupaten Muna 2019)

One of the rice-producing districts in Muna District is Kabangka Sub District, Lupia Village. Lupia Village is one of the villages which has an area of $13.20 \mathrm{~km} 2$ and has a population of 364 families. Most of the people in Lupia Village make a living as farmers and from their income, they can meet their daily needs. Meanwhile, one of the potentials in Lupia Village is the potential of the agricultural sector, namely the food crop sector such as rice fields (Lupia Village Profile) This village has a rice field area of 50 ha, every year the rice plants in Lupia Village are able to produce $3-4$ tonnes of rice/ha with supportive land. Lowland rice farmers, amounting to 70 farmers (Lupia Village Farmers Group).

Paddy rice farming, to increase rice production requires knowledge of the use of production factors so as to increase rice production with a high selling value so that farmers' income can increase. The purpose of this study is to analyze what factors influence the production of lowland rice farming in Lupia Village, Kabangka Sub District, Muna District, where rice farmers use production factors to increase production. 


\section{MATERIALS AND METHODS}

This research was conducted in Lupia Village, Kabangka Sub District, Muna District in February - March 2020. The selection of research locations was determined purposively. With the consideration that most of the people in the village work as lowland rice farmers with 70 farmers and one of the villages has a large enough rice field area, namely 50 ha, with unstable rice production due to production factors that can affect income farmers (Lupia Village Farmers Group) and no one has conducted research in the village. The population in this study were all lowland rice farmers in Lupia Village, Kabangka Sub District, Muna District, totaling 70 farmers. Sampling was done by a simple random sampling method, with an accuracy level of 90 percent so based on the Slovin formula, the number of samples selected in Lupia Village, Kabangka Sub District, Muna District, was 42 farmers. To find out what factors affect the size of the production, the data analysis method used in this study is a regression using the Cobb-Douglas production function model. Factors that affect the size of lowland rice farming are land area, labor, seeds, fertilizers, and pesticides. . Mathematically, the Cobb-Douglas function can be written as the following equation (Soekartawi. 1989).

$$
\mathrm{Y}=\mathrm{a} \cdot \mathrm{X}_{1}^{\mathrm{b} 1} \cdot \mathrm{X}_{2}^{\mathrm{b} 2} \cdot \mathrm{X}_{3}^{\mathrm{b} 3} \cdot \mathrm{X}_{4}^{\mathrm{b} 4} \cdot \mathrm{X}_{5}^{\mathrm{b5}} \cdot \mathrm{X}_{6}^{\mathrm{b} 6} \cdot \mathrm{e}^{\mathrm{u}}
$$

To facilitate estimation of the above formula, the equation is converted into multiple linear by means of the equation being:

Information :

$$
\operatorname{Ln} Y=\ln a+b_{1} \ln X_{1}+b_{2} \ln X_{2}+b_{3} \ln X_{3}+b_{4} \ln X_{4}+b_{5} \ln X_{5}+b_{6} \ln X_{6}+u
$$

$Y=$ Production $(\mathrm{Kg} /$ Season)

$\mathrm{X} 1=$ Area of Land $(\mathrm{Ha})$

$\mathrm{X} 2$ = Labor (HOK)

$\mathrm{X} 3=$ Seed $(\mathrm{Kg})$

$X 4=$ Urea Fertilizer $(\mathrm{Kg})$

$\mathrm{X} 5=\mathrm{NPK}$ Fertilizer $(\mathrm{Kg})$

$\mathrm{X} 6=$ Pesticides $(\mathrm{L})$

$\mathrm{a}, \mathrm{b}=$ Quantity to be predicted

$\mathrm{u}=$ Errors (disturbance term)

$\mathrm{e} \quad=$ Natural logarithm, $\mathrm{e}=2.718$.

This study uses a level of $\alpha=0.1$ or an error rate of $10 \%$ or an accuracy level of $90 \%$.

\section{RESULTS AND DISCUSSION}

\section{Respondent Characteristics}

The identity of the respondent is a description of the socio-economic condition of the respondent which influences the farmer's ability to manage his farm. The sample used in this study were 42 farmers in Lupia Village, several characteristics of respondents according to age level, farming experience, number of family dependents, level of education, and number of workers.

Table 1.Characteristics of paddy paddy farmers based on age group in Lupia Village, Kabangka Sub District, Muna District

\begin{tabular}{lcc}
\hline \multicolumn{1}{c}{ Variable } & Number (people) & Percentage (\%) \\
\hline Age (Years) & 29 & 69,05 \\
Productive (15-54) & 13 & 30,95 \\
Non-Earning (>55 & & \\
\hline Level of education & 18 & 42,86 \\
Completed Elementary School/equivalent & 5 & 11,90 \\
Completed Junior High School/equivalent & 19 & 45,24 \\
Graduated from high school/equivalent & 38 & \\
\hline Number of dependents (soul) & 3 & 90,48 \\
1 - 4 (small) & 4 & 9,52 \\
$>$ 4 (large) & 8 & 19,05 \\
\hline Business Experience (Years) & 12 & 28,57 \\
Less Experience (<5) & 22 & 52,38 \\
Sufficiently Experienced (5-10) & &
\end{tabular}

Source: Primary Data, 2020 
Age level is one of the factors that affect the production level of farmers who are at productive age who have optimal conditions for carrying out production activities in an effort to increase production yields. Table 1 shows that of the 42 respondents of lowland rice farmers in Lupia Village, Kabangka Sub District, Muna District, 29 people (69.05\%) are in the productive age category while the remaining 13 people (30.95\%) are in the age category. not productive. This is in accordance with the statement (Damayanti. 2013) which states that the age of rice farmers will affect their physical ability to manage the business they are engaged in. The working ability of a rice farmer will increase to a certain age level, then it will decrease. The older the farmers, the ability to work relatively decreases. Age can be used as an indicator of a farmer's ability to accept innovations or new ideas in advancing his business.

The physical abilities and thinking abilities of lowland rice farmers in Lupia Village are still in a productive condition. The age level of a farmer is very influential on increasing productivity to earn income because generally, older farmers have limited physical abilities compared to younger farmers. Sometimes also more often need help from other family members to complete all these agricultural activities. So that farmers who are old have low productivity and usually produce lowland rice only to meet their daily needs and not for sale.

Formal education is an important aspect of determining the mindset and actions of a farmer. According to (Tuwo 2011), stating that education generally affects the way farmers think. High education at a relatively young age will cause farmers to be more dynamic. The higher the level of formal education of the respondent farmers, the broader their knowledge and insight will be so that there is a tendency to accept innovation more. The education referred to in this research is formal education

Table 1 shows that of the 42 respondents of lowland rice farmers in Lupia Village, Kabangka Sub District, Muna District, in general, they have not received a formal education, with the result that the percentage of respondents who have taken formal education at the primary school (SD) level is 18 people or $42.86 \%$ There were 5 respondents who took junior high school (SMP) or $11.90 \%$, and 19 people or $45.24 \%$ of those who took high school education. From the explanation of the results of the table above, it can be concluded that the data of respondents of lowland rice farmers are dominated by Senior High School (SMA) graduates, namely 19 people or $45.24 \%$ of the total sample size, so it can be concluded that lowland rice farmers in Lupia Village Kabangka Sub District, Muna District is still relatively low. Their knowledge of cultivating lowland rice has been passed down from generation to generation from their parents. The number of dependents in the family is a family member who lives in one house, where the farmers pay for their daily needs. The greater the number of family dependents, the greater the effort made by a farmer in helping the family to meet their daily needs, but when the family members are productive enough, the growth of family members will reduce the burden on the family in meeting household needs.

Table 1 shows that the number of dependents for each respondent to lowland rice farmers is more dominant in small families, namely 38 people with a percentage of $90.48 \%$, and respondents in large families as many as 4 people with a percentage of $9.52 \%$. Based on the results of the study, the number of dependents of the Lupia Village community is included in the category of small families. The number of family dependents will affect the level of welfare in the life of the farmer. The more the number of family members that are covered, the more income that must be allocated to finance life in the household.

Farming experience is an educational process that is obtained outside of school and has an important meaning for lowland rice farmers in managing their farming. According to (Tuwo 2011), said that experience is the best teacher for farmers. Experience can be a reference in preparing steps in the future. Experienced farmers will be more courageous in taking risks (risk takers) because they are able to overcome the things that will happen in their farming.

Table 1 shows that the experience of lowland rice farmers in Lupia Village is more dominant in the experienced category (>10 years) with a percentage of $52.38 \%$ of the 42 respondents. Thus, it is hoped that farmers will be able to be more skilled in managing their farms so that production can increase and the income they receive can also increase. This is in accordance with the opinion (Edyson et al., 2015), that the long experience in farming has made farmers more mature and more careful in making decisions in their farming.

\section{Classic Assumption Test}

The classic assumption deviation test is that a good regression model is a regression model that is free from multicollinearity and heteroscedasticity. Tests for deviations from classical assumptions were obtained with the help of the SPSS program version 21. The results of the classical assumption tests are as follows: 
The problem of classical regression assumptions lies not only in the relationship between data in one variable but also the relationship between independent variables. If two or more independent variables in the regression model have a close linear relationship, then this regression model is symptomatic of multicollinearity conditions (Gani, 2018).

The multicollinearity test aims to test whether the regression model finds a correlation between the independent variables. In a good regression model, there should be no correlation between the independent variables or the independent variables (Muliyanti 2019). The test method commonly used to determine whether there are multicollinearity symptoms in a regression model is to look at the Tolerance and VIF (variance inflation factor) values. If the tolerance value $>0.1$ and VIF $<10$, then the regression model does not have multicollinearity. If the tolerance value $<0.1$ and VIF $>$ 10 , then the regression model has multicollinearity.

The multicollinearity test results with the help of SPSS version 21 explain that the multicollinearity test results can be said to not occur multicollinearity because the VIF value is less than 10 and the Tolerance value is greater than 0.1 . Land area (X1) Tolerance value of 0.208 , labor (X2) Tolerance value of 0.804 , seeds (X3) Tolerance value of 0.173 , urea fertilizer (X4) Tolerance value of 0.477 , NPK Phonska fertilizer (X5), Tolerance value of 0.430 , and pesticide (X6) with a Tolerance value of 0.476 . So it can be concluded that the data contained in this study does not occur multicollinearity because the Tolerance value is greater than 0.1 so that it can be stated that the model does not have multicollinearity symptoms. The test results can be seen in Table 2 as follows:

Table 2. Multicollinearity test results

\begin{tabular}{lcc}
\hline \multirow{2}{*}{ Model } & \multicolumn{2}{c}{ Collinearity Statistics } \\
\cline { 2 - 3 } (Constanta) & Tolerance & VIF \\
Land area & 0,208 & 4,798 \\
Labor & 0,804 & 1,244 \\
Seed & 0,173 & 5,792 \\
Urea fertilizer & 0,477 & 2,095 \\
Phonska NPK fertilizer & 0,430 & 2,326 \\
Pesticide & 0,476 & 2,103 \\
\hline
\end{tabular}

Source: Primary Data, 2020

Heteroscedasticity is a condition in which the variance and residual values are not all between one observation and another. The heteroscedasticity test aims to test whether in the regression model there is an inequality of variance and residuals from one observation to another. If the variance and residual value are equal (equal) between one other observation, then this condition is called the homoscedasticity condition. A good regression is a regression that is in a homoscedasticity position and not a heteroscedasticity condition (Gani, 2018). To see whether there is heteroscedasticity in this study, it can be done using the Scatterplot chart method, from these results it can be seen that the dots have spread, not forming any clumping pattern. It can be concluded that the regression model indicates no heteroscedasticity problem. The results of heteroscedasticity testing with the Scatterplot chart method can be seen in Figure 1.

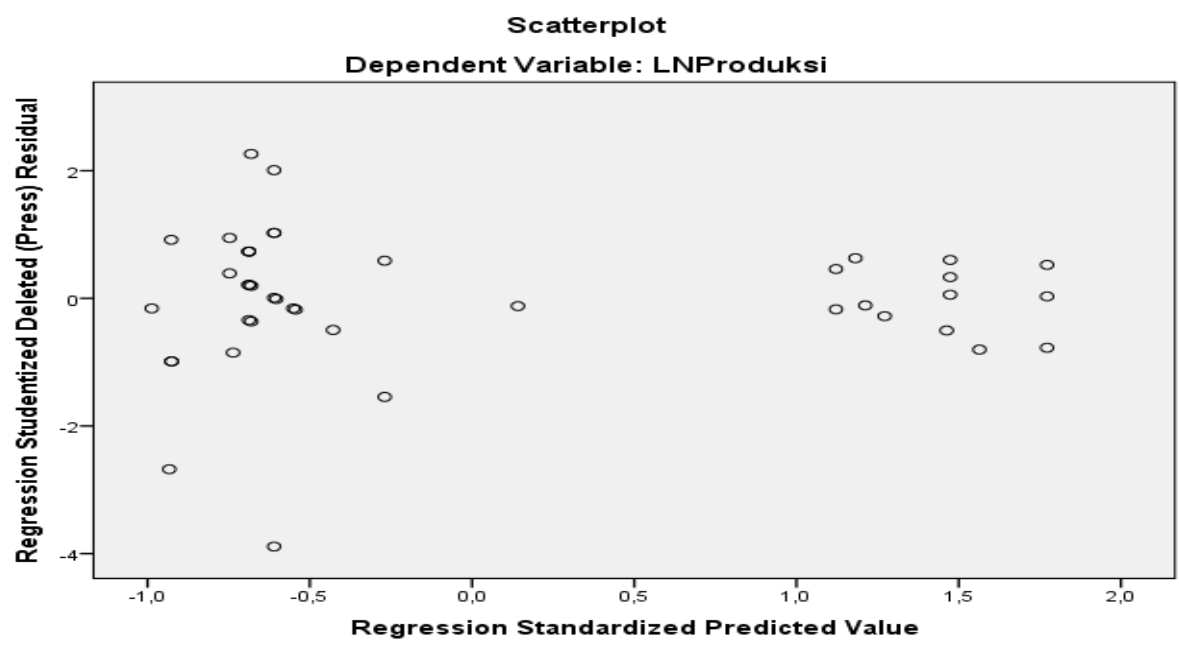

Figure 1. Results of heteroscedasticity testing using the scatterplot chart method 


\section{The Coefficient of Determination $\left(R^{2}\right)$ and The $F$ Test}

The coefficient of determination $\left(R^{2}\right)$ is a measure used to determine the influence of the independent variable on the dependent variable. With the criteria of $R^{2}=1$, the appropriate model explains all variability in variable $Y$. If $R^{2}=0$ then there is no relationship between variable $X$ and variable $Y$ (Muliyanti 2019). The results of this study explain that the coefficient of determination or $R$ Square is 0.884 or equal to $88.4 \%$. This value means that the relationship between variables or the coefficient of determination which shows how good the regression model is formed by the independent variables and the dependent variable. The coefficient of determination obtained by $88.4 \%$ of respondent farmers who do lowland rice farming can be determined by land area (X1), labor (X2), seeds (X3), urea fertilizer (X4), NPK Phonska fertilizer (X5), pesticide (X6) affects the production variable $(Y)$ by $88.4 \%$, while the remaining $11.6 \%$ is influenced by other variables not included in the model. The results of the analysis of the coefficient of determination and the $F$ test can be seen in Table 3 as follows:

Table 3. The results of the determination coefficient test and the $F$ test

\begin{tabular}{lccccc}
\multicolumn{1}{c}{ Model } & Sum of Squares & $\mathrm{df}$ & Mean Square & $\mathrm{F}$ & Sig. \\
\hline Regression & 4,461 & 6 &, 743 & 44,468 &, $000^{\mathrm{b}}$ \\
Residual &, 585 & 35 &, 017 & & \\
Total & 5,046 & 41 & & & \\
\hline R &, $940^{\mathrm{a}}$ & & & & \\
\hline R-square &, 884 & & & & \\
\hline Adjusted R Square &, 864 & & & & \\
\hline
\end{tabular}

Source: Primary Data, 2020

The $\mathrm{F}$ test is used to determine whether all independent variables, namely land area, labor, seeds, urea fertilizer, Phonska NPK fertilizer, and pesticides included in the model or equation have a joint effect on the dependent variable (production). The results of this study explained that Sig. is equal to 0.000 . Because of the Sig. $0.000<0.1$, then according to the basis of decision making in the $\mathrm{F}$ test it can be concluded that $\mathrm{HO}$ is rejected or $\mathrm{Ha}$ is accepted. So it can be concluded that the variables studied significantly influence the production of lowland rice farming in Lupia Village, Kabangka Sub District, Muna District.

\section{T-test}

This test is used to see how much influence the independent variables are, namely land area $\left(X_{1}\right)$, labor $\left(X_{2}\right)$, seeds $\left(X_{3}\right)$, urea fertilizer $\left(X_{4}\right)$, Npk fertilizer $\left(X_{5}\right)$, and pesticides $\left(X_{6}\right)$ individually (individually itself) on the dependent variable, namely production $(\mathrm{Y})$. Based on the table, it can be explained that the effect of each independent variable $(X)$ partially (individually) on rice farming production $(\mathrm{Y})$. Production factors that affect lowland rice production, namely land area, seeds and pesticides, and labor production factors, urea fertilizer, and NPK Phonska fertilizer do not affect lowland rice production in Lupia Village, Kabangka Sub District, Muna District.

Table 4. Multiple linear regression test

\begin{tabular}{|c|c|c|c|c|}
\hline Model & $B$ & $\mathrm{t}$ & Sig. & information \\
\hline (Constanta) & 4,094 & 4,328 &, 000 & ** \\
\hline LN Land Area &,- 326 & $-2,559$ & 015 & ** \\
\hline LN Manpower &,- 004 &,- 045 & ,965 & ns \\
\hline LN Seeds & 1,011 & 3,197 & ,003 & ** \\
\hline LN Urea Fertilizer & 167 & 1,498 & 143 & ns \\
\hline LN NPK Phonska Fertilizer &,- 049 &,- 370 & ,713 & ns \\
\hline LN Pesticides & 1,409 & 9,129 &, 000 & ** \\
\hline
\end{tabular}

Source: Primary Data, 2020

Based on the results of data analysis as presented in Table 4, the regression equation is changed in the form of the Cobb-Douglas model equation, so that the equation becomes:

1. Land Area $\left(X_{1}\right)$

$$
Y=0,6073 \cdot X_{1}^{-0,326} \cdot X_{2}^{-0,004} \cdot X_{3}^{1,011} \cdot X_{4}^{0,167} \cdot X_{5}^{-0,049} \cdot X_{6}^{1,409} \cdot e^{u}
$$

Based on Table 4, it is known that the $t$ value for land area $t=-2.559$ with a significant level of 0.015 (smaller than $\alpha=0.1$ ), so Ho is rejected. So it can be said that the variable land area has a significant effect on lowland rice production in Lupia Village, Kabangka Sub District, Muna District. 
The estimation result of the regression coefficient for the land area is -0.326 , which means that the regression coefficient value is equal to zero or it will not increase production but is statistically significant at the level of $\alpha=0.1$. So, the land area has a significant effect on lowland rice production.

2. Labor $\left(\mathrm{X}_{2}\right)$

Based on Table 4, it is known that the $t$ value for labor is $t=-0.045$ with a significant level of 0.965 (greater than $\alpha=0.1$ ), then $\mathrm{Ho}$ is accepted. So it can be said that the labor variable has no significant effect on lowland rice production in Lupia Village, Kabangka Sub District, Muna District. The estimation result of the regression coefficient value is equal to zero or it will not increase production and it is not statistically significant at the level of $\alpha=0.1$. So, labor has no significant and negative effect on lowland rice production. This is in accordance with the results of research (Puspitasari, 2017) which shows that labor has no significant and negative effect on production with a significance level of 0.944 . This is because the labor used is quite large and varied, besides being the biggest cost in lowland rice farming.

3.Seed $\left(\mathrm{X}_{3}\right)$

Based on Table 4 it is known that the $t$-count value for seeds $t=3.197$ with a significant level of 0.003 (smaller than $\alpha=0.1$ ), so Ho is rejected. So it can be said that the seed variable has a significant effect on lowland rice production in Lupia Village, Kabangka Sub District, Muna District. The estimation result of the seed regression coefficient is 1.011, which means that every 1 percent increase in the value of seeds will increase the amount of lowland rice production by 1.011 percent. So, seeds have a positive value and have a significant effect on lowland rice production.

4. Urea Fertilizer $\left(\mathrm{X}_{4}\right)$

Based on Table 4 it is known that the $t$ value for urea fertilizer $t=1.498$ with a significant level of 0.143 (greater than $\alpha=0.1$ ), then $\mathrm{Ho}$ is accepted. So it can be said that the urea fertilizer variable has no significant effect on lowland rice production in Lupia Village, Kabangka Sub District, Muna District. The estimation result of the urea fertilizer regression coefficient is 0.167 , which means that every 1 percent increase in the value of urea fertilizer will increase the amount of lowland rice production by 0.167 percent. So, urea fertilizer has no significant and positive value, this is because the nitrogen element in urea has a positive impact on the growth of lowland rice. This is not in accordance with research (Jumiati, 2016), which shows that urea has a positive and significant effect on rice production.

5. Phonska NPK Fertilizer $\left(X_{5}\right)$

Based on Table 4 it is known that the $t$ value for NPK Phonska fertilizer $t=-0.370$ with a significant level of 0.713 (greater than $\alpha=0.1$ ), then Ho is accepted. So it can be said that the NPK Phonska fertilizer variable has no significant effect on lowland rice production in Lupia Village, Kabangka Sub District, Muna District. The estimation result of the NPK Phonska fertilizer regression coefficient is -0.049 , which means that every 1 percent increase in the value of NPK Phonska fertilizer will have an impact on decreasing the amount of production by -0.049 percent. So, Phonska NPK fertilizer is negative and has no significant effect on lowland rice production. This is in accordance with the statement (Puspitasari, 2017) which states that the effect of using NPK Phonska fertilizer on certified seeds on rice production is -0.005 . The test results show that this variable is not significant but negative to the production with a significant level of 0.890 .

6. Pesticides $\left(\mathrm{X}_{6}\right)$

Based on Table 4, it is known that the $t$-value for pesticides is $t=9,129$ with a significant level of 0,000 (smaller than $\alpha=0.1$ ), so Ho is rejected. So it can be said that the pesticide variable has a significant effect on lowland rice production in Lupia Village, Kabangka Sub District, Muna District. The estimation result of the pesticide regression coefficient is 1.409 , which means that every 1 percent increase in pesticide value will increase the amount of lowland rice production by 1.409 percent. So, pesticides have a significant and positive effect on lowland rice production. This shows that pesticide production factors greatly affect lowland rice production. This is supported by a statement (Puspitasari, 2017) which states that pesticides have no significant but positive effect on rice production with a significance level of 0.461 . Thus it can be said that pesticides have a positive effect on production, where if the use of certified seeds is increased by 1 percent, then rice production will increase by 0.050 percent.

\section{CONCLUSIONS AND SUGGESTIONS}

Based on the results of the research that has been conducted, several conclusions have been drawn that from the results of the regression analysis, it can be seen that the factors that significantly influence the production of lowland rice farming are land area (X1), seeds (X2) and pesticides (X6). For lowland rice farmers, in order for lowland rice farming production in Lupia Village, Kabangka Sub 
District, Muna District to achieve optimal results, farmers need to increase the use of seed production factors and increase the use of pesticides in order to produce the desired rice production.

\section{REFERENCE}

BPS Kabupaten Muna (2019). Kabupaten Muna Dalam Angka 2019. Badan Pusat Statistik Kabupaten Muna. Sulawesi Tenggara.

Damayanti., L. (2013). Faktor-Faktor Yang Mempengaruhi Produksi, Pendapatan dan Kesempatan Kerja Pada Usaha Tani Padi Sawah di Daerah Irigasi Parigi Moutong. Sepa 9(2): 249-259.

Edyson, M. D.A., Timisela, N. R,, \&Luhukay, J.M. (2015). Analisis Tingkat Kelayakan Usahatani Padi Sawah (Oryza sativa L) (Studi Kasus Di Desa Wanareja Kecamatan Waepo Kabupaten Buru). Jurnal Agrilan 3(2): 179-190.

Gani. I, S. A. (2018). Alat Analisis Data: Aplikasi Statistik untuk Penelitian Bidang Ekonomi dan Sosial Edisi Revisi. CV Andi Offset. Yogyakarta

Jumiati (2016). Analisis Faktor-Faktor Yang Mempengaruhi Produksi Padi Di Kecamatan Sinjai Selatan Kabupaten Sinjai. Universitas Negeri Makassar. Makassar

Muliyanti, S. (2019). Faktor- Faktor yang Mempengaruhi Produksi Padi Sawah (Oriza sativa L) Kelurahan Unaasi Kecamatan Anggaberi Kabupaten Konawe. Universitas Halu Oleo. Kendari

Puspitasari, M. S. (2017). Analisis Efisiensi Penggunaan Faktor Produksi Pada Usahatani Padi dengan Menggunkan Benih Bersertifikat dan Non Sertifikat di Desa Air Satan Kecamatan Muara Beliti Kabupaten Musi Rawas. Societa. 4(1): 46-56.

Soekartawi. (1989). Prinsi Dasar Ekonomi Pertanian. CV Rajawali. Jakarta Utara

Tuwo, M. A. (2011). Ilmu Usahatani: Teori Dan Aplikasi AMenuju Sukses.Unhalu Press. Kendari

Utama, Z. H. (2015). Budidaya Padi Pada Lahan Marjinal. CV Andi Offset. Yogyakarta 